\title{
A synopsis of Ptilotus (Amaranthaceae) in eastern Australia
}

\author{
A.R. Bean \\ Queensland Herbarium, EPA, Brisbane Botanic Gardens, Mt Coot-tha Road, Toowong, \\ Queensland 4066, Australia \\ Email: tony.bean@epa.qld.gov.au
}

\begin{abstract}
A synopsis is presented for the 31 Ptilotus species accepted by the author, and indigenous in eastern Australia (Queensland, New South Wales, Victoria and Tasmania). Notes on typification, distribution and habitat are given. Two new combinations are made, and 24 names are here formally reduced to synonymy. A lectotype is chosen for P. calostachyus F.Muell. A key to the identification of Ptilotus taxa in eastern Australia is included.
\end{abstract}

\section{Introduction}

Ptilotus is a genus comprising around 100 species, virtually confined to Australia, but with one species ( $P$. conicus R.Br.) extending to Timor and adjacent islands. The majority of species occur in arid or semi-arid areas, with a centre of species diversity in Western Australia, where numerous species await formal naming. In eastern Australia (comprising Queensland, New South Wales (including Australian Capital Territory), Victoria and Tasmania), no undescribed species are known to occur.

In the latter half of the 20th century Ptilotus taxonomy was dominated by Gerhard Benl, a botanist based in Munich, Germany. He wrote many papers devoted to the taxonomy and nomenclature of Ptilotus, of which some of the main works were Benl $(1958,1959,1967 a, 1971,1981)$.

Benl's apparent desire to document all observed morphological variation in a formal manner i.e. by describing new subspecies, varieties and formae of new or established species, based on one or few specimens, has resulted in a hideously complex nomenclature for the genus. While many of Benl's new species are "good", the infraspecific taxa, in very many cases, have proven to be of no practical taxonomic value, with the diagnosed differences being just part of the variation to be expected for a species. In addition, Australian users of Benl's papers have been hampered by the (often) German text, the cumbersome identification keys, and the sometimes erroneous, misleading or scanty diagnosis of taxa.

Ptilotus species (as with species of other genera and families) exhibit variation in many of their characteristics, both within and between populations. Often this variation is 
continuous and not correlated between characters, so that subdivision of species is meaningless and arbitrary. Perhaps because Benl was geographically remote from natural populations of Ptilotus and relied on intermittent specimen loans, he may never have seen the full range of variation exhibited by many species. Differences that appeared significant to him on one or a few specimens were often just part of the variation that is continuous within a species. The full range of variation can be observed only by seeing plants of different ages and sizes and from different regions and growing conditions. This is ideally achieved through field studies and observations, but a comprehensive set of herbarium specimens can be almost as informative. Through a combination of field work and herbarium study, the present author is confident of the synonymies and taxonomic concepts proposed in this paper.

The aim of this paper is to present a summary of the Ptilotus taxa in eastern Australia. Thirty one taxa of Ptilotus are accepted (29 species, one subspecies and one variety) as indigenous in eastern Australia. An identification key is provided, using readily observable characters. Two new combinations (Ptilotus nobilis subsp. semilanatus and $P$. capensis) are made here, 24 names are placed formally into synonymy and P. calostachyus is lectotypified.

Type specimens, or images of types, have been seen for nearly all taxa for which nomenclatural changes are proposed. Names based on types from Western Australia, South Australia and Northern Territory have not (with some exceptions) been considered in this treatment. Types not seen have been annotated with "n.v."

Specimens have been received on loan from AD, BM, CANB, K, MEL, and NSW and the entire holdings of BRI and MEL have been examined. In addition, images of type specimens have been received from B, CGE and LD. Tepal length measurements here include the fused basal portion, i.e. from the base of the perianth to the tip of the longest tepal. Accepted taxa are arranged in alphabetical order.

\section{Taxonomy}

\section{Key to the eastern Australian taxa of Ptilotus}

1 Inflorescences in the axils of fully-developed leaves; plants having the appearance of an Alternanthera or Aerva

2 Tepals 2-3.5 mm long; bracteoles 1-2 mm long P. murrayi

$2^{*}$ Tepals 4-5 mm long; bracteoles 4-5.5 mm long P. decipiens

$1^{\star}$ Inflorescence terminal, or pseudo-terminal (i.e. borne in the axils of reduced upper leaves)

3 Fully expanded leaves glabrous or with scattered hairs only

4 Flowers at basal end of inflorescence widely spaced ( $>3 \mathrm{~mm}$ apart)

5 Tepals 12-15 mm long; leaves 35-70 mm long, margins entire; plant 50-70 cm high

P. capensis

5* Tepals 9-11 mm long; leaves 8-15 mm long, margins undulate; plant up to 30 $\mathrm{cm}$ high 
$4^{\star}$ Flowers \pm densely packed, $<1 \mathrm{~mm}$ apart

6 Tepals 17-44 mm long

7 Tepals with long septate hairs only

P. macrocephalus

$7^{\star}$ Tepals with short verticillate ${ }^{\#}$ hairs as well as long septate hairs

P. nobilis subsp. nobilis

$6^{\star}$ Tepals 3-17 mm long

8 Tepals $10-17 \mathrm{~mm}$ long

9 Petioles (of the basal leaves) well-developed, always more than half lamina length and sometimes longer than lamina

10 Inflorescence cylindrical; tepals 10-14 mm long, pale green

P. spathulatus

$10^{*}$ Inflorescences globose to ovoid; tepals $12-15 \mathrm{~mm}$ long

11 Stems erect, to $40 \mathrm{~cm}$ high; tepals without short verticillate hairs; all tepal hairs septate, not exceeding ends of tepals.

P. indivisus

$11^{\star}$ Stems sprawling, to $30 \mathrm{~cm}$ high; verticillate hairs $(0.2-1 \mathrm{~mm}$ long) present on tepals; longer tepal hairs septate, equalling or exceeding ends of tepals

P. seminudus

$9 *$ Petioles absent, obscure, or less than half lamina length

12 Outside of tepals with short verticillate ${ }^{\#}$ hairs as well as long septate hairs

13 Leaves rhombic, $<10 \mathrm{~mm}$ long

P. remotiflorus

$13^{\star}$ Leaves linear to narrowly-oblanceolate, $20-50 \mathrm{~mm}$ long P. nobilis subsp. semilanatus

$12^{\star}$ Outside of tepals with unbranched septate hairs only

14 Inflorescence globose to ovoid, $1.5-4 \mathrm{~cm}$ long; leaves linear, up to $4 \mathrm{~mm}$ wide

15 Tepals curved; southern Australia P. erubescens

$15^{\star}$ Tepals straight; northern Australia P. fusiformis

$14^{*}$ Inflorescence cylindrical, 3-12 cm long; leaves narrowlylanceolate or lanceolate, $4-20 \mathrm{~mm}$ wide ... P. polystachyus

$8^{*}$ Tepals $3-10 \mathrm{~mm}$ long

16 Lower leaves with distinct petiole as long as, or longer than lamina .. P. latifolius

$16^{\star}$ Leaves either without a distinct petiole, or petiole less than half the length of the lamina

\# verticillate hairs - those with a branching pattern very similar to an Araucaria tree (Norfolk Island Pine, for example), i.e. hair has a central 'column' with a number of verticillate branches 
17 Distal half of tepals glabrous

18 Tepals white to pink when fresh, 3.5-4.5 mm long; peduncles 1-10 mm long, glabrous at $1 \mathrm{~mm}$ below base of inflorescence

P. corymbosus

$18^{\star}$ Tepals red to maroon when fresh, 4.2-6 mm long; peduncles 30-130 mm long, sparsely hairy at $1 \mathrm{~mm}$ below base of inflorescence P. spicatus

$17^{\star}$ Tepals hairy throughout or almost throughout

19 Inflorescences pink to purple

20 Apex of tepals truncate, erose; plants to $30 \mathrm{~cm}$ high P. leucocoma

$20^{\star}$ Apex of tepals acute; plants $0.6-2.5 \mathrm{~m}$ high

21 Inflorescences erect, 1-4 cm long, apex rounded P. schwartzii

$21^{\star}$ Inflorescences \pm pendulous, (3-)4-10 cm long, apex conical P. calostachyus

$19^{\star}$ Inflorescences white to greenish-white

22 Tepals almost completely obscured by white woolly indumentum P. brachyanthus

$22^{\star}$ Hairs present, but tepals readily visible

23 Procumbent sub-shrub to $20 \mathrm{~cm}$ high; leaves narrowly oblanceolate, sparsely hairy; bracteoles $3.5-4.5 \mathrm{~mm}$ long P. gaudichaudii var. parviflorus

$23^{\star}$ Erect shrub 25-60 cm high; leaves filiform, glabrous; bracteoles $2.5-3.5 \mathrm{~mm}$ long P. fusiformis

$3^{\star}$ All leaves conspicuously (often densely) hairy, at least on lower surface

24 Leaves orbicular; inflorescences in sessile clusters

25 Inflorescences globose to ellipsoidal; tepals 5-7 mm long; fully developed leaves $10-25 \mathrm{~mm}$ long P. maconochiei

$25^{\star}$ Inflorescences narrowly cylindrical; tepals $4-5 \mathrm{~mm}$ long; fully developed leaves 6-10 mm long...... P. royceanus

$24^{\star}$ Leaves narrowly-lanceolate to broadly ovate; inflorescences pedunculate 26 All leaf hairs simple (uniseriate)

27 Tepals 16-21 mm long P. clementii

$27^{\star}$ Tepals 5-9 mm long 
28 Tepals 7-9 mm long; filaments 3-4 mm long; anthers $0.45-0.6 \mathrm{~mm}$ long, at least some exserted on dried specimens; style 3.2-3.7 mm long

P. helipteroides

$28^{*}$ Tepals 5-7 mm long; filaments $1-1.8 \mathrm{~mm}$ long; anthers $0.2-0.4 \mathrm{~mm}$ long, none exserted on dried specimens; style 1-1.6 mm long

P. pseudohelipteroides

$26^{*}$ Leaf hairs stellate, dendritic or verticillate

29 Tepals 10-17 mm long

30 Tepals deep pink; spikes $1-3 \mathrm{~cm}$ long

P. sessilifolius

$30^{\star}$ Tepals white, grey or greenish; spikes $3-18 \mathrm{~cm}$ long ...P. polystachyus

$29 *$ Tepals $4-10 \mathrm{~mm}$ long

31 Leaves strongly discolorous, margins revolute; tepals $4-5 \mathrm{~mm}$ long

P. pedleyanus

$31^{\star}$ Leaves \pm concolorous, margins flat; tepals 5.5-10 mm long

32 Peduncles not branching, each $0-3 \mathrm{~mm}$ long, with inflorescences scattered along branchlets; lower leaves with very dense hairs $0.7-$ $1.5 \mathrm{~mm}$ long

P. incanus

$32 \star$ Peduncles branching, each 3-30 mm long, often giving rise to a corymbose conflorescence; lower leaves with moderate to dense cover of hairs $0.2-0.7 \mathrm{~mm}$ long

P. obovatus

Ptilotus brachyanthus (Benth.) F.Muell., Syst. Census Austral. Pl. 29 (1883)

Trichinium brachyanthum Benth., Fl. Austral. 5: 239 (1870).

Type: 'North-west Australia', 1856, F. Mueller s.n.; holo MEL; iso K.

Elliot \& Jones, Encycl. Australian Pl., Volume 8: 104 (2002).

Ptilotus blakeanus Benl, Austrobaileya 1: 446 (1983), syn. nov.

Type: Queensland. Chesterton, 7 April 1936, S.T. Blake 11107; holo BRI.

Elliot \& Jones, Encycl. Australian Pl., Volume 8: 104 (2002).-

Illustration: Benl (1983: 449, t. 30).

Distribution and habitat: there are pre-1900 records of $P$. brachyanthus from 'Peak Downs' (in 1872) and 'Burenda Downs' (late 1800's), both in Qld. In the $20^{\text {th }}$ century, it was collected from a few places between Augathella and Longreach. It is otherwise known only from Mueller's type collection, presumably from the western part of the N.T. It is likely that the absence of records between Longreach and western N.T. is due to habitat modification and overgrazing. Habitat is poorly known but some collections describe the habitat as woodland dominated by Acacia cambagei.

Notes: P. blakeanus was described by Benl, based on a single specimen at BRI. He distinguished it from $P$. brachyanthus by the non-clustered spikes, the apical shape of the spikes, the colour of the inflorescence, the woollier stems, and the foliage being less dense. These characteristics are either trivial or continuously variable, and the variation 
exhibited by P. brachyanthus easily encompasses the type specimen of P. blakeanus.

Ptilotus calostachyus F.Muell., Fragm. 6: 231 (1868)

Trichinium calostachyum (F.Muell.) Benth., Fl.Austral. 5:236 (1870); Ptilotuscalostachyus F.Muell. var. calostachyus, Mitt. Bot. Staatssamml. München 2: 405 (1958).

Type: Western Australia. Roebuck Bay, undated, J. Martin s.n.; lecto MEL, here chosen. Benl, Fl. Cent. Austral. 82 (1981); Wheeler, Fl. Kimb. 124 (1992); Elliot \& Jones, Encycl. Australian Pl., Volume 8: 104 (2002)..

Trichinium procerum Diels, Bot. Jahrb. Syst. 35: 191 (1904); Ptilotus calostachyus var. procerus (Diels) Benl, Mitt. Bot. Staatssamml. München 2: 405 (1958), syn. nov.

Type: Western Australia. De Witt, near Nichol Bay, undated, L. Diels 2803; holo B, digital image at BRI.

Illustrations: Erickson et al., Fl. \& Pl. of W. Aust. 2nd edition 163 (1979); Elliot \& Jones, Encycl. Australian Pl., Volume 8: 104 (2002); Moore, Guide Pl. Inland Australia 254 (2005).

Distribution and habitat: $P$. calostachyus is known from two localities north of Camooweal in Qld, both very close to the N.T. border. The species is widespread and common in central N.T. and the northern half of W.A. It inhabits sandy or stony plains and ridges.

Notes: Mueller cited three specimens in the protologue - one of his own, one by Martin and one by Walcott. The Mueller specimen could not be found at MEL. Of the two other syntypes, the Martin collection is the better quality specimen, and is here chosen as the lectotype.

Benl distinguished P. calostachyus var. procerus from $P$. calostachyus sens. str. by the supposedly longer spikes, bracts more hirsute and the smaller staminodial scales. When a range of specimens is examined, it is clear that these characteristics are variable and not correlated. The spike length and other macroscopic features on the type of T. procerum are typical for $P$. calostachyus, and furthermore the type locality of T. procerum coincides with that of one of the former syntypes of T. calostachyus.

Ptilotus capensis (Benl) A.R.Bean, comb. et stat. nov.

Ptilotus distans subsp. capensis Benl, Austrobaileya 2: 17 (1984).

Type: Queensland. Thursday Island, June 1897, F.M. Bailey 114; holo BRI.

Bentham, Fl. Austral. 5: 223-4 (1870), P. distans in part; Elliot \& Jones, Encycl. Australian Pl., Volume 8: 108 (2002), P. distans in part.

Illustration: Benl (1984: 18, fig. 1).

Distribution and habitat: $P$. capensis is endemic to Qld, extending on the islands of the Torres Strait, throughout Cape York Peninsula, and south to Kidston. It grows in open eucalypt woodland on shallow or deep sandy soils, or on reddish lateritic loams.

Notes: this taxon was given subspecies rank by Benl (1984). He distinguished $P$. distans subsp. capensis from $P$. distans sens. str. by the filaments $8-9.5 \mathrm{~mm}$ long (vs. $2.5-3 \mathrm{~mm}$ long for $P$. distans sens. str.), the style c. $7.5 \mathrm{~mm}$ long with an inconspicuous stigma (vs. style 1.3-2.2 mm long, stigma conspicuous and capitate), the hairs on top of the ovary erect, ciliate, articulate, to $3.3 \mathrm{~mm}$ long (vs. short spreading non-articulate 
pubescence to $1.4 \mathrm{~mm}$ long) and the outer surface of the bracts hairy throughout (vs. glabrous for $P$. distans sens. str.). I find that these differences are distinctive and consistent. In addition, the flowers of $P$. capensis are always stipitate, with stipes $0.5-1$ $\mathrm{mm}$ long, while in $P$. distans sens. str. they are sessile. As was stated by Benl (loc. cit.), there is no intergradation between the two taxa. Hence specific rank is appropriate for this taxon.

Ptilotus clementii (Farmar) Benl, Mitt. Bot. Staatssamml. München 2: 405 (1958)

Trichinium clementii Farmar, Bull. Herb. Boissier ser. 2, 5: 1088 (1905).

Type: Western Australia. between the Ashburton and De Grey Rivers, 1897, E. Clement; holo K, n.v.

Benl, Fl. Cent. Austral. 79 (1981); Elliot \& Jones, Encycl. Australian Pl., Volume 8: 105-6 (2002).

Ptilotus pearsonii C.T.White, Proc. Roy. Soc. Queensland 53: 225 (1942).

Type: Queensland. Soldier's Gap area, Cloncurry, July 1941, S.E. Pearson 112; holo BRI; iso $\mathrm{GH}$, n.v.

Illustration: Moore, Guide Pl. Inland Australia 254 (2005).

Distribution and habitat: in eastern Australia, P. clementii is confined to the Mt IsaCloncurry area of north-west Qld. However, it is widespread in arid or semi-arid areas of N.T. and W.A., west to the Cape Range. It grows on stony hills in low open woodland dominated by eucalypts or acacias, or in Triodia grassland. Soils may be loamy or clayey.

Ptilotus corymbosus R.Br., Prodr. 415 (1810)

Trichinium corymbosum (R.Br.) Spreng., Syst. Veg. 1: 816 (1825), non Gaudich. (1829); Ptilotus corymbosus R.Br. var. corymbosus, Fl. Austral. 5: 243 (1870).

Type: [Northern Territory] Carpentaria Island 's' [Morgan Is.], 20-21 January 1803, $R$. Brown [Bennett No. 3055]; holo BM; iso K.

Bentham, Fl. Austral. 5: 242-3 (1870); Wheeler, Fl. Kimb. 124, 126 (1992); Elliot \& Jones, Encycl. Australian Pl., Volume 8: 106 (2002).

Ptilotus corymbosus var. acutiflorus Benth., Fl. Austral. 5: 243 (1870), syn. nov.

Type: Northern Territory. North coast of Arnhem Land, 1862, McKinlay s.n.; holo MEL (2 sheets).

Illustration: Wheeler (1992: 127, t. 32A).

Distribution and habitat: $P$. corymbosus is confined (in eastern Australia) to the Lawn Hill area, north of Camooweal in north-west Qld. However, it is widespread in the northern half of N.T., and as far west as Broome in W.A. It typically inhabits stony ridges and hillsides with skeletal soil.

Ptilotus decipiens (Benth.) C.A.Gardn., Enum. Pl. Austral. Occid.: 41 (1930)

Alternanthera decipiens Benth., Fl. Austral. 5: 251 (1870).

Type: [Queensland] subtropical New Holland, 1846, T.L. Mitchell 510; holo ?K, n.v.

Benl, Fl. Cent. Austral. 80 (1981); Benl, Fl. South Austral. 1: 325 (1986); Elliot \& Jones, Encycl. Australian Pl., Volume 8: 107 (2002). 
Ptilotus hoodii F.Muell., Fragm. 8: 232 (1874).

Type: [Northern Territory] Mt Olga, 1873, E. Giles s.n.; holo MEL (2 sheets).

Distribution and habitat: P. decipiens has a rather scattered occurrence in western Qld as far east as Jericho, but is more common in arid parts of N.T. and S.A., and extends just into W.A. It grows on rocky hill slopes with skeletal soil.

Note: A.W.Hill, Index Kew. 8:199 (1933) is sometimes given as the secondary author, on the grounds that Gardner's combination (in Enum. Pl. Austral. Occid., 1930) was not validly made because he failed to adequately refer to the basionym. However, Article 33.2 of the Code (see also Ex. 5) states that, before 1953, an indirect reference to a basionym is sufficient for valid publication of a new combination.

Ptilotus erubescens Schltdl., Linnaea 20: 575 (1847)

Trichinium erubescens (Schltdl.) Moq. in A.DC., Prodr. 13(2): 293 (1849).

Type citation: South Australia. Dry hills near Gawlertown, undated [1844-47], H.H. Behr s.n.; holo ?HAL, n.v.

Cunningham et al. (1981: 285); Jacobs \& Lapinpuro, Fl. N.S.W. 1: 259 (1990); Elliot \& Jones, Encycl. Australian Pl., Volume 8: 109 (2002).

Illustrations: Jacobs \& Lapinpuro (1990: 259); Walsh (1996: 211, t. 37m-n).

Distribution and habitat: . erubescens is found in S.A., from the Flinders Ranges to south of Adelaide, and in the western half of Vic., and extending just into N.S.W. (near Deniliquin). It grows in grassland and woodland communities on relatively fertile soils.

Ptilotus extenuatus Benl, Telopea 2: 147 (1981)

Type: New South Wales, anno 1818, C. Fraser 54; holo BM, n.v., fide Benl, Telopea 2: 147 (1981).

Jacobs \& Lapinpuro, Fl. N.S.W. 1: 257-8 (1990); Elliot \& Jones, Encycl. Australian Pl., Volume 8: 110 (2002).

Illustrations: Benl, Telopea 2: 149-50, Fig. 1, 2 (1981); Jacobs \& Lapinpuro (1990: 258).

Distribution and habitat: just four widely scattered collections of $P$. extenuatus have been made. In N.S.W., it is known from the type and one other collection. In Qld it has been collected twice in the far south of the state. The habitat is unknown. One specimen label records the soil as 'grey silty clay' while another says 'light sandy soil'.

Note: this species is listed as 'Presumed Extinct' in New South Wales, under the Threatened Species Conservation Act in that state.

Ptilotus fusiformis (R.Br.) Poir. in Lam., Encycl. Suppl. 4: 619 (1816)

Trichinium fusiforme R.Br., Prodr. 415 (1810); Trichinium fusiforme R.Br. var. fusiforme, Pl. Preiss. 1: 627 (1845); Trichinium fusiforme var. typicum Domin, Biblioth. Bot. 89: 82 (1921), nom. illeg.; Ptilotus fusiformis (R.Br.) F.Muell. var. fusiformis, Mitt. Bot. Staatssamml. München 3: 36 (1959).

Type: [Northern Territory] island in the Gulf of Carpentaria [North Island], 16/17 December 1802, R. Brown [Bennett No. 3052]; holo BM; iso MEL. 
Bentham, Fl. Austral. 5: 234-5 (1870); Benl, Fl. Cent. Austral. 82 (1981); Wheeler, Fl. Kimb. 126, 128 (1992); Elliot \& Jones, Encycl. Australian Pl., Volume 8: 110-11 (2002).

Trichinium gracile R.Br., Prodr. 415 (1810); Ptilotus gracilis (R.Br.) Poir. in Lam., Encycl. Suppl. 4: 620 (1816); Trichinium fusiforme var. gracile (R.Br.) Domin, Biblioth. Bot. 89: 82 (1921) Ptilotus fusiformis var. gracilis (R.Br.) Benl, Mitt. Bot. Staatssamml. München 3: 36 (1959), syn. nov.

Type: [Northern Territory] islands of the Gulf of Carpentaria [islands v, s \& c], 1803, $R$. Brown [Bennett No. 3053]; holo BM; iso K, MEL.

Bentham, Fl. Austral. 5: 235 (1870).

Illustrations: Wheeler (1992: 127, t. 32E); Milson, Pasture Pl. N.W. Qld 11 (2000); Moore, Guide Pl. Inland Australia 256 (2005).

Distribution and habitat: P. fusiformis is very widely distributed across northern Australia, excluding high-rainfall or densely forested areas, from the Pilbara region of W.A., to around Collinsville in Qld. It inhabits a wide range of sites on sandy or loamy soils.

Notes: the Ptilotus combinations made by Poiret in Encycl. Suppl. appear to satisfy the requirements of Article 33.1 of the ICBN, because the generic epithet is definitely associated with the species epithet. Hence these combinations are validly published.

The type of T. gracile has tepals around $8 \mathrm{~mm}$ long, while the type of T. fusiforme has tepals 12 or $13 \mathrm{~mm}$ long. On that basis, Brown was quite justified in thinking there were distinct species. However, we now know that these collections represent the extremes of a continuum in tepal length for this species.

Ptilotus gaudichaudii var. parviflorus (Benth.) Benl, Mitt. Bot. Staatssamml. München 3: 36 (1959)

Trichinium corymbosum var. parviflorum Benth., Fl. Austral. 5: 226 (1870); Hemisteirus psilotrichoides F.Muell., Linnaea 25: 435 (1852); Ptilotus hemisteirus F.Muell., Fragm. 4: 90 (1864), nom. illeg.

Type: South Australia. Cudnaka, October 1851, F. Mueller s.n.; holo MEL.

Cunningham et al. (1981: 286), in part; Benl, Fl. South Austral. 1: 327 (1986); Jacobs \& Lapinpuro, Fl. N.S.W. 1: 258-9 (1990); Elliot \& Jones, Encycl. Australian Pl., Volume 8: 111 (2002).

Illustration: Jacobs \& Lapinpuro (1990: 258, 259).

Distribution and habitat: in eastern Australia, P. gaudichaudii var. parviflorus is widespread in southern Qld and western N.S.W. It is also found in southern W.A. and S.A.

Note: P. gaudichaudii var. parviflorus is a decumbent plant to $25 \mathrm{~cm}$ high, with greenishgrey tepals 7-9 mm long, and narrowly spathulate leaves. From my own limited field observations and from examination of herbarium material, $P$. gaudichaudii var. gaudichaudii seems quite distinct from it. The latter is an erect plant to $60 \mathrm{~cm}$, with bright yellow tepals 11-15 mm long, and filamentous leaves. Further study may reveal that these taxa are separable at species rank. 
Ptilotus helipteroides (F.Muell.) F.Muell., Fragm. 6: 231 (1868)

Trichinium helipteroides F.Muell., Fragm. 3: 122 (1862); Trichinium helipteroides F.Muell. var. helipteroides, Fl. S. Austral. 2: 212 (1924); Ptilotus helipteroides (F.Muell.) F.Muell. var. helipteroides, Suppl. Fl. S. Austral. 2: 130 (1965)

Type: Western Australia. Nickol Bay, 1862, P. Walcott; holo MEL; iso MEL.

Bentham, Fl. Austral. 5: 231 (1870); Benl, Fl. Cent. Austral. 80 (1981); Benl, Fl. South Austral. 1: 327 (1986); Elliot \& Jones, Encycl. Australian Pl., Volume 8: 112 (2002).

Illustrations: Erickson et al., Fl. \& Pl. of W. Aust. 2nd edition 146 (1979); Elliot \& Jones, Encycl. Australian Pl., Volume 8: 113 (2002); Moore, Guide Pl. Inland Australia 257 (2005).

Distribution and habitat: this species is widespread across arid Australia, from the west coast of W.A., southern N.T., northern S.A., and east to Boulia in western Qld. It inhabits grasslands, herblands or Acacia aneura open woodland on hills or plains, with red gravelly soils.

Ptilotus incanus (R.Br.) Poir. in Lam., Encycl. Suppl. 4: 620 (1816)

Trichinium incanum R.Br., Prodr. 415 (1810); Trichinium incanum R.Br. var. incanum, Proc. Roy. Soc. Victoria ser.2, 22: 97 (1909); Ptilotus incanus (R.Br.) Poir. var. incanus, Mitt. Bot. Staatssamml. München 3: 38 (1959).

Type: Western Australia. West coast of New Holland [probably Shark Bay], anno 1801, O. Baudin s.n.; syn BM.

Bentham, Fl. Austral. 5: 221-2 (1870); Benl, Fl. Cent. Austral. 79 (1981); Benl, Fl. South Austral. 1: 327 (1986); Wheeler, Fl. Kimb. 128 (1992); Elliot \& Jones, Encycl. Australian Pl., Volume 8: 113-4 (2002).

Trichinium incanum var. parviflorum Ewart \& Jean White, Proc. Roy. Soc. Victoria 22: 97 (1909); Ptilotus incanus var. parviflorus (Ewart \& Jean White) Benl, Mitt. Bot. Staatssamml. München 3: 38 (1959), syn. nov.

Type: South Australia. NE of Mt Illillinna, Elder Explor. Exped. Camp 4, 9 June 1891, R. Helms s.n.; holo MEL.

Ptilotus incanus var. elongatus Benl, Mitt. Bot. Staatssamml. München 4: 278 (1961), syn. nov.

Type: Northern Territory. 52 miles [84 km] N of Tennant Creek township, 26 April 1948, R.A. Perry 631; holo CANB; iso BRI, MEL.

Ptilotus obovatus var. griseus Benl, Trans. Roy. Soc. South Australia 88: 58 (1964), syn. nov.

Type: Northern Territory. Mt Olga area, 16 August 1959, E.N.S. Jackson 118; holo AD; iso MEL.

Illustrations: Wheeler (1992: 129, t. 33A),

Distribution and habitat: in eastern Australia, P. incanus is confined to the Mt IsaCloncurry area of north-west Qld. However, it is widespread in arid Australia, including the Pilbara region of W.A., the southern N.T., and the northern parts of S.A. It grows on rocky hills with eucalypts or Acacia spp. and Triodia spp.

Notes: Benl maintained P. incanus var. parviflorus, originally established by Ewart and 
White, and distinguished it from typical $P$. incanus by its fewer flowered inflorescences and the "loose" hairs on the stems and leaves. The inflorescences on the type specimen of T. incanum var. parviflorum are immature, and this alone accounts for the fewer visible flowers. There is no discernable difference in the indumentum pattern.

Benl erected another variety (var. elongatus); the type of this name has rather short hairs, as in P. obovatus, but features the sessile or subsessile inflorescences that are a feature of $P$. incanus. It is possibly a hybrid between these two species. The gradation of characters for $P$. incanus does not warrant the recognition of varieties within it.

Ptilotus indivisus Benl, Mitt. Bot. Staatssamml. München 3: 38 (1959)

Trichinium gomphrenoides Moq. in A.DC., Prodr. 13(2): 287 (1849); Ptilotus gomphrenoides (Moq.) F.Muell., Syst. Census Austral. Pl. 28 (1883), nom. illeg., non Benth. (1870).

Type Citation: "South Coast of New Holland, Drummond”. Type: "S.C. of N. Holland, Strutt [or Sturtt] s.n."; holo K.

Distribution and habitat: $P$. indivisus is known only from four specimens, all from the Mudgee and Parkes districts, on the central western slopes of N.S.W. The habitat is unknown.

Notes: I have examined the type specimen of Trichinium gomphrenoides from Kew. This specimen bears a slip saying "Trichin gomphrenoides Moq." in the distinctive handwriting of Alfred Moquin-Tandon, and it has been annotated by Benl as $P$. indivisus.

The person who wrote the label saying "S.C. of N. Holland, Strutt" for the holotype is unknown. It seems very likely that Charles Sturt is the collector intended, with the following as evidence: the geographical range of $P$. indivisus coincides with areas Sturt visited during his expeditions; there appears to be no record of a "Strutt" associated with botany or plant collecting in Australia; and the type of P. leucocoma, which undoubtedly was collected by Sturt, bears a label in the same handwriting, saying "N.W. interior N.H., Capt. Strutt".

As the type citation agrees so well with the label of the specimen at Kew (with the exception of the collector name), it seems likely that this is the holotype. Moquin stated that the type was "v.s. in h. Hook." or "seen dried in the Hooker herbarium". The Hooker herbarium is now incorporated in Kew. It is presumed that Moquin mistakenly wrote the name Drummond instead of Sturt.

Specimens that Benl determined as P. indivisus from the central western slopes of N.S.W. are a good match for the type. Ptilotus indivisus seems closely related to P. seminudus; their distributions apparently do not overlap in N.S.W., with P. indivisus occurring further to the east. There is an urgent need for field surveys to determine the current population size and extent of $P$. indivisus. On current knowledge, it should be regarded as an endangered species. There are just three specimens at NSW, with the most recent being 1964. The single specimen at MEL (from Mudgee) is dated 1880.

Ptilotus latifolius R.Br., Bot. Sturt's Exped. p. 88 (1849)

P. latifolius var. latifolius, Mitt. Bot. Staatssamml. München 3: 39 (1959).

Type: [Queensland?] in latitude 265, undated [1844-45], C. Sturt s.n.; holo BM. 
Bentham, Fl. Austral. 5: 244 (1870); Benl, Fl. Cent. Austral. 80 (1981); Cunningham et al. (1981: 287); Benl, Fl. South Austral. 1: 328 (1986); Jacobs \& Lapinpuro, Fl. N.S.W. 1: 259 (1990); Elliot \& Jones, Encycl. Australian Pl., Volume 8: 114-5 (2002).

Ptilotus latifolius var. major Benl, Mitt. Bot. Staatssamml. München 3: 39 (1959), syn. nov. Type: Western Australia. Hamersley Range, near Mt Rica, 26 October 1941, C.A. Gardner 6429; holo MEL; iso PERTH, n.v.

Illustrations: Cunningham et al. (1981: 287); Benl (1986: 325, t. 185B); Jacobs \& Lapinpuro (1990: 259); Moore, Guide Pl. Inland Australia (2005: 257).

Distribution and habitat: a widespread species in arid parts of Australia from far western Qld and north-western N.S.W., across southern N.T. and northern S.A., to the Pilbara coast of W.A. It typically inhabits the crests of sand dunes, but may be present in other sandy free-draining locations.

Note: the variety major is well within the range of variation for the species, and specimens with the characteristics of var. major can be found in most populations of P. latifolius.

Ptilotus leucocoma (Moq.) F.Muell., Syst. Census Austral. Pl. 1: 29 (1883)

Trichinium leucocoma Moq. in A.DC., Prodr. 13(2): 292 (1849).

Type citation: “in Nova-Hollandia (herb. Hook!)”. Type: N.W. [north-west] interior [of] N.H. [New Holland], undated [1828-29], Capt. Strutt [C. Sturt s.n.]; holo K.

Bentham, Fl. Austral. 5: 238 (1870); Benl, Fl. Cent. Austral. 80-1 (1981); Cunningham et al. (1981: 287); Jacobs \& Lapinpuro, Fl. N.S.W. 1: 259 (1990); Elliot \& Jones, Encycl. Australian Pl., Volume 8: 115 (2002).

Ptilotus calostachyus var. kennediae Ewart \& Jean White, J. Proc. Roy. Soc. New South Wales 42: 193 (1908).

Type: New South Wales. Tandarlo via Wilcannia, Darling River, anno 1886, W.B. Kennedy s.n.; holo MEL.

[Ptilotus kennediae F.Muell., nom. nud.]

Ptilotus humifusus Benl, Sendtnera 1: 39 (1993), syn. nov.

Type: Queensland. 40 km S of Cunnamulla, 29 July 1983, P.E. Conrick 1484; holo AD; iso BRI, CANB, n.v.

Illustrations: Cunningham et al. (1981: 287); Jacobs \& Lapinpuro (1990: 259); Benl, Sendtnera 1: 44, t. 2 (1993), as P. humifusus; Milson, Pl. Ident. in Arid Zone 29 (1995).

Distribution and habitat: P. leucocoma is mainly distributed from near Wilcannia in western N.S.W. to Windorah in Qld, but with two outlying localities, viz. Cloncurry, and $60 \mathrm{~km} \mathrm{~W}$ of Urandangie. Records from W.A. are likely to refer to another (probably unnamed) species. Ptilotus leucocoma grows on sandy-loam soils with Acacia aneura or on stony hills with Eremophila or Senna spp.

Notes: Chapman (1991) gave the spelling of the epithet as leucocomus, but as the epithet is a noun in apposition, it is not declinable as an epithet. Therefore leucocoma is correct.

The type of P. humifusus matches P. leucocoma in every way, and would appear to be merely a young plant of that species. Benl's epithet humifusus means 'creeping, prostrate'. 
Prostrate and procumbent plants of $P$. leucocoma are readily found. It is significant that Benl did not diagnose $P$. humifusus against $P$. leucocoma, but only against $P$. procumbens from Western Australia.

Ptilotus maconochiei Benl, J. Adelaide Bot. Gard. 1: 201 (1979)

Type: Queensland. City lookout, Mt Isa, 8 March 1978, G. Benl Au64 \& J. Maconochie; holo M, n.v.; iso BRI, MEL.

Elliot \& Jones, Encycl. Australian Pl., Volume 8: 115 (2002).

Illustration: Benl, J. Adelaide Bot. Gard. 1: 202-3, t. 1, 2 (1979)

Distribution and habitat: P. maconochiei is endemic to Qld, where it is moderately widespread, though sporadic, from Mt Isa in the north to Windorah in the south. It grows on stony hills and residuals with Acacia spp.

Ptilotus macrocephalus (R.Br.) Poir. in Lam., Encycl. Suppl. 4: 620 (1816)

Trichinium macrocephalum R.Br., Prodr. 415 (1810).

Type: Australia. South coast, collector unknown; holo ?BM, n.v.

Bentham, Fl. Austral. 5: 225-6 (1870); Benl, Fl. Cent. Austral. 82 (1981); Cunningham et al. (1981: 287); Benl, Fl. South Austral. 1: 328 (1986); Jacobs \& Lapinpuro, Fl. N.S.W. 1: 258 (1990); Wheeler, Fl. Kimb. 130 (1992); Walsh, Fl. Victoria 3: 209 (1996); Elliot \& Jones, Encycl. Australian Pl., Volume 8: 116 (2002).

Trichinium angustifolium Moq. in A.DC., Prodr. 13(2): 293 (1849).

Type: New South Wales. Hunter's River, A. Cunningham s.n.; iso G-DC, microfiche.

Trichinium pachocephalum Moq. in A.DC., Prodr. 13(2): 294 (1849); Ptilotus pachocephalus (Moq.) F.Muell., Fragm. 6: 228 (1868).

Type: [Victoria]. Port Phillip, southern Australia, ?R. Gunn; holo ?FI, n.v.

Illustrations: Cunningham et al. (1981: 287); Jacobs \& Lapinpuro (1990: 258); Wheeler (1992: 131, t. 34B); Milson, Pl. Ident. in Arid Zone 29 (1995); Walsh (1996: 211, t. 37g-h); Elliot \& Jones, Encycl. Australian Pl., Volume 8: 116 (2002); Moore, Guide Pl. Inland Australia 258 (2005).

Distribution and habitat: P. macrocephalus is very widespread in Qld, N.S.W. and Vic., mainly in arid areas, but also in some higher rainfall areas close to the coast. It is also widespread in S.A., N.T. and W.A. It grows in a wide range of habitats, including alluvium, stony plains and steep hills, but it is absent from cracking clay or coarse sandy soils.

Note: the tepal length (and hence the 'brush' or inflorescence width) is variable in this species. Plants with the longest tepals (up to $44 \mathrm{~mm}$ long) are found in north-eastern Queensland, while plants from other near-coastal areas of Qld and N.S.W. have tepals almost as long. Plants from W.A. have the shortest tepals, typically about $18 \mathrm{~mm}$ long. Examination of herbarium specimens from across the continent suggests that the variation is clinal.

Ptilotus murrayi F.Muell, Fragm. 3: 145 (1863

Ptilotus murrayi F.Muell. var. murrayi, Trans. \& Proc. Roy. Soc. South Australia 47: 368 (1923). 
Type: [state unknown]. From the flooded tracts of Wills Creek, beyond desert, 1861, J. Murray s.n.; holo MEL.

Bentham, Fl. Austral. 5: 243-4 (1870); Benl, Fl. Cent. Austral. 82 (1981); Benl, Fl. South Austral. 1: 328 (1986); Wheeler, Fl. Kimb. 130 (1992); Elliot \& Jones, Encycl. Australian Pl., Volume 8: 118 (2002).

Ptilotus murrayi var. major J.M.Black, Trans. \& Proc. Roy. Soc. South Australia 47: 368 (1923), syn. nov.

Type: South Australia. Between Herrgott and Innamincka, June 1916, R. Cockburn s.n.; holo AD [AD97747822A, left-hand specimen only].

Illustration: Wheeler (1992: 131, t. 34C).

Distribution and habitat: P. murrayi is common in south-western Qld, the far northeastern part of S.A., and in the southern Kimberley region of W.A. Strangely, it is not yet recorded for the N.T. (D. Albrecht pers. comm. 2007). P. murrayi inhabits alluvial areas, favouring heavy cracking clay soil, often in association with Eucalyptus coolabah and Chenopodium auricomum.

Notes: the holotype of P. murrayi var. major is mounted on the same sheet as a collection made from the Diamantina River in August 1930. As the latter was collected after the publication of the name, only the left-hand specimen is type material.

Ptilotus murrayi var. major is not worthy of recognition as a separate taxon. Black separated his new variety based on the larger stems and leaves, the longer inflorescences 8-30 mm long and the perianth 3-4 mm long. The dimensions of the leaves and stems of the type are readily duplicated in other collections of $P$. murrayi. A couple of the inflorescences of the type do reach $30 \mathrm{~mm}$ long. This is longer than in most other collections of P. murrayi, but there is a continuum of inflorescence lengths, with no correlation to other characters. Black gave the perianth length as " $3-4 \mathrm{~mm}$ ", but the longest perianth I could find on the type measured $3.5 \mathrm{~mm}$. This conforms with collections of $P$. murrayi from other parts of its range.

Ptilotus nobilis (Lindl.) F.Muell., Fragm. 6: 227 (1868)

Trichinium nobile Lindl. in T.Mitch., Three Exped. Australia 2: 23 (1838).

Type: New South Wales. "interior of New Holland" [Lachlan River, near Condobolin], 2 April 1836, T.L. Mitchell 50; holo CGE, digital image at BRI.

Bentham, Fl. Austral. 5: 224-5 (1870); Benl, Fl. Cent. Austral. 81 (1981); Cunningham et al. (1981: 288); Benl, Fl. South Austral. 1: 328-9 (1986); Jacobs \& Lapinpuro, Fl. N.S.W. 1: 258 (1990); Walsh, Fl. Victoria 3: 209 (1996); Elliot \& Jones, Encycl. Australian Pl., Volume 8: 118 (2002).

Ptilotus exaltatus Nees in Lehm., Pl. Preiss. 1: 630 (1845); Trichinium exaltatum (Nees) Benth., Fl. Austral. 5: 227 (1870); Ptilotus exaltatus Nees var. exaltatus, Census NSW Pl. 72 (1916), syn. nov.

Type: Western Australia. Avon River, between the farms of Messrs Heals and Whitfield, March 1840, L. Preiss 1367; holo LD, digital image at BRI.

Bentham, Fl. Austral. 5: 227 (1870); Cunningham et al. (1981: 285); Benl, Fl. South Austral. 1: 326 (1986); Jacobs \& Lapinpuro, Fl. N.S.W. 1: 258 (1990); Wheeler, Fl. Kimb. 126 (1992); Walsh, Fl. Victoria 3: 212 (1996); Elliot \& Jones, Encycl. Australian Pl., Volume 8: 109 (2002). 
Notes: there has long been contention about the taxonomic difference or lack of difference between $P$. nobilis and the typical form of $P$. exaltatus. Bentham (1870) distinguished them by the presence or absence of woolly hairs on the inside of the tepals, but this character is not consistent. Benl (1971) additionally used the odour of the leaves as a distinguishing feature. The only other available difference has been flower colour, but populations have been found where both colour forms (pale yellow vs. purple) are present (M. Johnston, pers. comm. 2006).

Lee et al. (2007) have presented strong genetic evidence for the merging of these two species, a course that I have followed. However, it seems desirable to continue to recognise semilanatus as an infraspecific taxon, as it is readily morphologically distinguishable in most instances. The rank of subspecies is considered appropriate, as $P$. nobilis subsp. nobilis and P. nobilis subsp. semilanatus have separate "core" areas with a north-south zone of intergradation in central New South Wales and Queensland.

Two subspecies are recognised here:

a. Ptilotus nobilis (Lindl.) F.Muell. subsp. nobilis

Trichinium densum A.Cunn. ex Moq. in A.DC., Prodr. 13(2): 289 (1849).

Type: New South Wales. Swampy-plains near Lachlan River, June 1817, A. Cunningham s.n.; holo G-DC, microfiche; iso CGE, digital image at BRI.

Trichinium macrocephalum Moq. in A.DC., Prodr. 13(2): 290 (1849), nom. illeg., non R.Br. (1810).

Type: Western Australia. Careening Bay, 1820, A. Cunningham 202; iso BM.

Trichinium burtonii F.M.Bailey, Bull. Dept. Agric. Queensland 7: 14 (1891).

Type: Queensland. Between Camooweal and Urandangi towards Georgina R., anno 1890, R.C. Burton s.n.; holo BRI; iso MEL.

Trichinium nervosum F.M.Bailey, Queensland Agric. J. 25: 287 (1910).

Type: Queensland. Georgina River, September 1910, E.W. Bick 51; syn BRI; ditto, E.W. Bick 50; syn BRI.

Illustrations: Erickson et al., Fl. \& Pl. of W. Aust. 2nd edition 146 (1979), as P. exaltatus; Cunningham et al. (1981: 285), as P. exaltatus var. exaltatus, (1981: 288); Benl (1986: 329, t. 186A); Jacobs \& Lapinpuro (1990: 258); Wheeler (1992: 127, t. 32D); Milson, Pl. Ident. in Arid Zone 29 (1995), as P. exaltatus var. exaltatus; Walsh (1996: 211, t. 37e-f, o-p); Milson, Pasture Pl. N.W. Qld 10 (2000), as P. exaltatus var. exaltatus; Elliot \& Jones, Encycl. Australian Pl., Volume 8: 117 (2002); Moore, Guide Pl. Inland Australia 255 (as P. exaltatus), 258 (2005).

Distribution and habitat: $P$. nobilis subsp. nobilis is widely distributed in W.A., N.T., S.A., far north-western Vic., western N.S.W. and western Qld. It is found in a variety of habitats, including Acacia woodland, mallee-eucalypt woodland, shrubland or grassland, on red sands, sandy loams or clays, occasionally on stony sites.

Note: flower colour may be purple-pink (plants previously known as P. exaltatus var. exaltatus) or creamy-white to greenish-white (plants previously known as $P$. nobilis). Both colour forms may be present in one population. 
b. Ptilotus nobilis Nees subsp. semilanatus (Lindl.) A.R.Bean comb. et stat. nov.

Trichinium semilanatum Lindl. in T.Mitch., J. Exped. Trop. Australia 45 (1848); Ptilotus exaltatus Nees var. semilanatus (Lindl.) Maiden \& Betche, Census N.S.W. Pl. 72 (1916); Ptilotus semilanatus (Lindl.) J.M.Black, Fl. S. Austral. 2nd edition, 327 (1948)

Type: New South Wales. Duck Creek [c. 25 km N of Nyngan], subtropical New Holland, 27 January 1846, T.L. Mitchell [or W. Stephenson] 74; holo CGE, digital image at BRI; iso MEL.

Bentham, Fl. Austral. 5: 227-8 (1870); Cunningham et al. (1981: 286); Benl, Fl. South Austral. 1: 326 (1986); Jacobs \& Lapinpuro, Fl. N.S.W. 1: 260 (1990); Walsh, Fl. Victoria 3: 212 (1996)

Trichinium pulchellum A.Cunn. ex Moq. in A.DC., Prodr. 13(2): 290 (1849). Type: New South Wales. Swampy plains near Lachlan River, 20 May 1817, A. Cunningham 20; iso BM, digital image at BRI, G-DC, microfiche, GH, n.v.).

Trichinium setigerum A.Cunn. ex Moq. in A.DC., Prodr. 13(2): 290 (1849).

Type: New South Wales. Interior of eastern Australia, 25 May 1817, A. Cunningham 19; iso G-DC, microfiche.

Ptilotus dissitiflorus var. longifolius Benl, Muelleria 1: 107 (1959), syn. nov. Type: Queensland. Port Denison [Bowen], 1874, E. Fitzalan; holo MEL.

Illustrations: Cunningham et al. (1981: 286), as P. exaltatus var. semilanatus; Jacobs \& Lapinpuro (1990: 260), as P. semilanatus; Walsh (1996: 211, t. 37q-r), as P. exaltatus var. semilanatus.

Distribution and habitat: $P$. nobilis subsp. semilanatus is widespread in the eastern half of Qld, eastern N.S.W. and in northern and north-western Vic. It possibly also occurs in S.A. It intergrades with $P$. nobilis subsp. nobilis, with the latter occurring in the lower rainfall areas. The zone of intergradation is small compared with the overall distribution of $P$. nobilis.

Notes: this subspecies differs from the typical subspecies by the inflorescences $2-5(-8)$ $\mathrm{cm}$ long (5-20 cm long in subsp. nobilis), with the apex truncate or obtuse (conical in subsp. nobilis), the tepals 14-17 $\mathrm{mm}$ long (17-24 $\mathrm{mm}$ long in subsp. nobilis), and the linear or narrowly-spathulate leaves 2-6(-10) mm wide, with undulate margins (10-40 $\mathrm{mm}$ wide, margins straight in subsp. nobilis). It is consistently purple flowered (except for plants currently included under $P$. nobilis var. angustifolius Benl).

Ptilotus nobilis var. angustifolius Benl (the type of which comes from the Flinders Range, S.A.) is probably a synonym of $P$. nobilis subsp. semilanatus, but as I have not seen the type, no formal synonymy is given here.

The type of $P$. dissitiflorus var. longifolius indisputably belongs here. The flowers at the base of the inflorescences are rather widely spaced (unusual for P. nobilis subsp. semilanatus), but otherwise the type conforms in every regard with this subspecies. The type locality is given as Port Denison, the old name for Bowen. Ptilotus nobilis subsp. semilanatus is not known from the immediate vicinity of Bowen, but the collection was probably made some distance inland. Some other Fitzalan collections of non-coastal species are similarly labelled 'Port Denison'. 
Ptilotus obovatus (Gaudich.) F.Muell., Fragm. 6: 228 (1868)

Trichinium obovatum Gaudich. in Freyc., Voy. Uranie Bot. 445, t. 49 (1829); Trichinium obovatum Gaudich. var.obovatum, Fl.Austral. 5:221 (1870); Ptilotus obovatus (Gaudich.) F.Muell. var. obovatus, Fl. N. Territory 100 (1917)

Type: Western Australia. Baie des Chiens-Marins [Shark Bay], C. Gaudichaud s.n.; syn G-DC, microfiche, GH, n.v., P, n.v.

Bentham, Fl. Austral. 5: 220-1 (1870); Benl, Fl. Cent. Austral. 79 (1981); Cunningham et al. (1981: 288); Benl, Fl. South Austral. 1: 329-30 (1986); Jacobs \& Lapinpuro, Fl. N.S.W. 1: 257 (1990); Walsh, Fl. Victoria 3: 208 (1996); Elliot \& Jones, Encycl. Australian Pl., Volume 8: 118-9 (2002).

Trichinium parviflorum Lindl. in T.Mitch., Three Exped. Australia 2: 12 (1838); Ptilotus parviflorus (Lindl.) F.Muell., Syst. Census Austral. Pl. 1: 28 (1883); Ptilotus obovatus var. parviflorus (Lindl.) Benl, Mitt. Bot. Staatssamml. München 3: 512 (1960), syn. nov.

Type: New South Wales. Interior of New Holland [Byrne's Creek, N.S.W.], 24 March 1836, T.L. Mitchell 24; holo CGE, digital image at BRI.

Trichinium lanatum Lindl. in T.Mitch., Three Exped. Australia 2: 123 (1838); Ptilotus lindleyi F.Muell., Fragm. 6: 233 (1868).

Type: [Australia] Interior of New Holland [Murray River], 8 June 1836, T.L. Mitchell 174; holo CGE, digital image at BRI.

Trichinium virgatum Moq. in A.DC., Prodr. 13(2): 286 (1849).

Type: New South Wales. Swampy-plains near Lachlan River, July 1817, A. Cunningham 17; holo G-DC, microfiche; iso: $\mathrm{K}$.

Trichinium variabile F.Muell., Linnaea 25: 436 (1853).

Type: South Australia. Barren plains between Flinders Range and Spencer Gulf, October 1851, F. Mueller s.n.; syn MEL (2 sheets).

Trichinium subviride Domin, Biblioth. Bot. 89: 81 (1921).

Type: Queensland. Near Cloncurry, January 1910, K. Domin; holo ?PR, n.v., fide Benl, Mitt. Bot. Staatssamml. München 3: 512 (1960).

Ptilotus obovatus var. lancifolius Benl, Mitt. Bot. Staatssamml. München 4: 279 (1961), syn. nov.

Type: Queensland. 13 miles [21 km] SSE of Kajabbi township, 29 August 1953, M. Lazarides 4006; holo CANB; iso BRI, MEL.

Illustrations: Cunningham et al. (1981: 288); Jacobs \& Lapinpuro (1990: 257); Milson, Pl. Ident. in Arid Zone 29 (1995); Elliot \& Jones, Encycl. Australian Pl., Volume 8: 104 (2002); Moore, Guide Pl. Inland Australia 259 (2005).

Distribution and habitat: $P$. obovatus is a very widespread species occurring in all mainland states, although in Vic. confined to the far north-west. It inhabits a wide range of sites, from steep stony hillsides to clayey flats, with a wide variety of associated species.

Note: the named varieties of $P$. obovatus are not worthy of recognition. Some are referable to other species (var. griseus, var. grandiflorus), while the others cannot be applied with any degree of certainty. While the species is very variable, there is no ecological or distributional pattern to the variation - plants with narrower leaves or smaller flowers or hairy ovaries can be found throughout the range of the species. 
Ptilotus pedleyanus Benl \& H.Eichler, Brunonia 4: 199 (1982)

Ptilotus pedleyanus var. pedleyanus, Brunonia 4: 205 (1982).

Type: Queensland. 'Grant' holding, NE of Barcaldine, July 1975, G.R. Beeston 1450C; holo BRI.

Elliot \& Jones, Encycl. Australian Pl., Volume 8: 119 (2002).

Ptilotus pedleyanus var. comosus Benl \& H.Eichler, Brunonia 4: 205 (1982), syn. nov. Type: Queensland. Cooladdi-Langlo Crossing road, $24 \mathrm{~km} \mathrm{~N}$ of Cooladdi, 1 October 1974, R.G. Silcock 433; holo BRI.

Distribution and habitat: $P$. pedleyanus is endemic to Qld, extending from Winton and Aramac in the north, to Quilpie in the south. It inhabits break-aways and other stony hills, with species such as Acacia catenulata and Eremophila spp.

Note: P. pedleyanus var. comosus is not worthy of recognition as a separate taxon. It represents minor variation within the species. Plants conforming to both of the named varieties can and do occur within the same population.

Ptilotus polystachyus (Gaudich.) F.Muell., Fragm. 6: 230 (1868)

Trichinium polystachyum Gaudich. in Freyc., Voy. Uranie Bot. 445 (1829); Ptilotus polystachyus var. polystachyus, Mitt. Bot. Staatssamml. München 7: 317 (1970); Ptilotus polystachyus f. polystachyus, Nuytsia 4: 273 (1983).

Types: Western Australia. Shark Bay, undated [September 1818], C. GaudichaudBeaupre; syn BM; syn G, n.v.; syn P, n.v., fide Benl (1983).

Bentham, Fl. Austral. 5: 225 (1870); Benl, Fl. Cent. Austral. 80 (1981); Cunningham et al. (1981: 289); Benl, Fl. South Austral. 1: 330-31 (1986); Wheeler, Fl. Perth Region 1: 97-8 (1987); Jacobs \& Lapinpuro, Fl. N.S.W. 1: 257 (1990); Wheeler, Fl. Kimb. 130, 132 (1992); Walsh, Fl. Victoria 3: 208 (1996); Elliot \& Jones, Encycl. Australian Pl., Volume 8: 120 (2002).

Trichinium alopecuroideum Lindl. in T.Mitch., Three Exped. Australia 2: 12 (1838); Ptilotus alopecuroideus (Lindl.) F.Muell., Fragm. 6: 227 (1868); Trichinium alopecuroideum Lindl. var. alopecuroideum, Trans. \& Proc. Roy. Soc. South Australia 40: 61 (1916); Ptilotus alopecuroideus (Lindl.) F.Muell. f. alopecuroideus, Mitt. Bot. Staatssamml. München 2: 402 (1958).

Type: New South Wales. Interior of New Holland [Byrnes Ck, N.S.W.], 24 March 1836, T.L. Mitchell s.n.; holo CGE, digital image at BRI; iso BM, K, MEL.

Bentham, Fl. Austral. 5: 224 (1870).

Trichinium conicum Lindl. in T.Mitch., J. Exped. Trop. Australia 363 (1848), nom. illeg., non Spreng. (1824).

Trichinium alopecuroideum var. rubriflorum J.M.Black, Trans. \& Proc. Roy. Soc. South Australia 40: 61 (1916); Ptilotus alopecuroideus f. rubriflorus (J.M.Black) Benl, Mitt. Bot. Staatssamml. München 2: 402 (1958); Ptilotus polystachyus f. rubriflorum (J.M.Black) Benl, Mitt. Bot. Staatssamml. München 3: 518 (1960), syn. nov.

Type: South Australia. Near Oodnadatta, November 1914, Staer s.n.; holo AD.

Ptilotus polystachyus var. arthrotrichus Benl, Mitt. Bot. Staatssamml. München 7: 317 (1970); Ptilotus polystachyus f. arthrotrichus (Benl) Benl, Nuytsia 4: 273 (1983), syn. nov. 
Type: Western Australia. 6 miles [10 km] N of Roeburne, 17 October 1941, C.A. Gardner 6323; holo PERTH, n.v.

Ptilotus polystachyus f. ruber Benl, Mitt. Bot. Staatssamml. München 15: 169 (1979), syn. nov.

Type: Western Australia. 28 km NE of Shay Gap, 22 July 1977, I.R. Telford 5985; holo CANB.

Illustrations: Cunningham et al. (1981: 289); Jacobs \& Lapinpuro (1990: 257); Wheeler (1992: 131, t. 34D); Milson, Pl. Ident. in Arid Zone 30 (1995); Walsh (1996: 211, t. 37c-d); Elliot \& Jones, Encycl. Australian Pl., Volume 8: 120 (2002); Moore, Guide Pl. Inland Australia 260 (2005).

Distribution and habitat: P. polystachyus is perhaps the most widespread of all Ptilotus species, occurring in all mainland states and the N.T., its range extending from near Inglewood in Qld to Shark Bay in W.A., and from Kakadu National Park and the Kimberley to north-western Vic. It occupies a wide range of habitats, but is most frequent in sandy or loamy soils of the inland, near sand-dunes or in Acacia aneura communities.

Notes: Benl (1983) discussed the variability of this species, and at that time he recognised four varieties and four formae. Most if not all of these varieties and formae are of no taxonomic consequence. For instance, f. rubriflorus is characterised by its spikes 'dull purple fading to brownish', but plants with this coloured inflorescence frequently occur in mixture with plants bearing the normal greenish-white spikes. One of the named varieties, P. polystachyus var. longistachyus, with its short tepals $(9-11 \mathrm{~mm}$ long) is perhaps worthy of that rank, but it is unclear to me whether it grades into the typical variety south of the Kimberley. A detailed taxonomic and ecological study of P. polystachyus would resolve this, but in the meantime, I believe the best course is to adopt a broadly circumscribed species.

Benl (1983) referred to the type specimen at BM as the holotype. The BM specimen comprises only inflorescences with a short section of stem and lacking any leaves. As Gaudichaud described the leaves in the protologue, the description was clearly not based solely on the BM material, and it should be referred to as a syntype.

Ptilotus pseudohelipteroides Benl, Muelleria 1: 105 (1959)

Type: Queensland. Currawilla, c. 100 miles [161 km] west of Windorah, 9 June 1949, S.L. Everist 3937; holo CANB; iso BRI.

Benl, Fl. Cent. Austral. 80 (1981); Elliot \& Jones, Encycl. Australian Pl., Volume 8: 120 (2002).

Trichinium helipteroides var. minor J.M.Black, Fl. S. Austral. 2: 212 (1924) and Trans. \& Proc. Roy. Soc. South Australia 48: 254 (1924); Ptilotus helipteroides var. minor (J.M.Black) H.Eichler, Suppl. Fl. S. Austral. 2: 130 (1965), syn. nov.

Type: South Australia. Blood's Creek, N of Oodnadatta, 20 July 1921, S.A. White 28; holo AD; iso K, n.v.

Benl, Fl. South Austral. 1: 327 (1986).

Distribution and habitat: P. pseudohelipteroides is distributed in far western Qld (Boulia to Thargomindah), south-eastern N.T. and northern S.A. It inhabits flats, gravelly rises and jump-ups. 
Notes: a comparison of the types of $P$. pseudohelipteroides and T. helipteroides var. minor finds them to be virtually identical, and they are clearly part of the same taxon. Benl, when describing $P$. pseudohelipteroides, made no mention of Black's variety.

The type of T. helipteroides var. minor is mounted with other non-type specimens. Only the material associated with the label "Bloods Creek 20.7.21" belongs to the holotype. A collection made by Cleland from Blood's Creek in January 1927 is not a part of the type.

Ptilotus remotiflorus Benl, Mitt. Bot. Staatssamml. München 12: 355 (1976).

Type: Queensland. 62 miles [100 km] west of Winton on the Boulia road, 19 March 1972, H. Reeve 81; holo CANB.

Ptilotus parvifolius var. laetus Benl, Mitt. Bot. Staatssamml. München 7: 315 (1970), syn. nov.

Type: New South Wales. Tero Creek station, c. 60 miles [96 km] NW of White Cliffs, 6 December 1968, B. Parker \& M. Stanger 112; holo CANB; iso MEL.

Cunningham et al. (1981: 288); Benl, Fl. South Austral. 1: 330 (1986); Jacobs \& Lapinpuro, Fl. N.S.W. 1: 259-60 (1990).

Illustrations: Cunningham et al. (1981: 288); Jacobs \& Lapinpuro (1990: 259), both as P. parvifolius var. laetus

Distribution and habitat: $P$. remotiflorus is distributed in a relatively narrow arc from Winton in Qld to the far north-west corner of N.S.W. It inhabits rocky or gravelly sites, typically the lower slopes of lateritic break-aways.

Note: the type of P. parvifolius var. laetus Benl matches P. remotiflorus in every regard.

Ptilotus royceanus Benl, J. Roy. Soc. Western Australia 53: 1 (1970).

Type: Western Australia. Bungabiddy rockhole, Walter James Range, 5 October 1966, A.S. George 8314; holo PERTH, n.v.; iso CANB, MEL.

Benl, Fl. Cent. Austral. 78 (1981); Elliot \& Jones, Encycl. Australian Pl., Volume 8: 122 (2002).

Illustration: Benl, J. Roy. Soc. W. Austral. 53: 2-3, t. 1, 2 (1970).

Distribution and habitat: $P$. royceanus has a remarkably disjunct distribution, found in the far east of W.A. (including the type locality), near Alice Springs in the N.T., and in the Idalia N.P. near Blackall in Qld. It grows on skeletal soils on rocky hills and ranges.

Note: the very widely spaced flowers of the type specimen of $P$. royceanus are not a feature of plants found in Queensland, or of other material collected from the type locality.

Ptilotus schwartzii (F.Muell.) Tate, Trans. Proc. \& Rep. Roy. Soc. South Australia 12: 82 (1889).

Ptilotus fraseri var. schwartzii F.Muell., Proc. Linn. Soc. New South Wales 3: 163 (1888);

Trichinium schwartzii (F.Muell.) Farmar, Bull. Herb. Boissier, sér. 2, 5; 1087 (1905).

Type: Northern Territory. Near the Macdonnell's Ranges, W.F. Schwartz s.n.; holo ?MEL, n.v. 
Benl, Fl. Cent. Austral. 82 (1981); Benl, Fl. South Austral. 1: 331 (1986); Elliot \& Jones, Encycl. Australian Pl., Volume 8: 122 (2002).

Illustrations: Milson, Pasture Pl. N.W. Qld 12 (2000); Elliot \& Jones, Encycl. Australian Pl., Volume 8: 122 (2002); Moore, Guide Pl. Inland Australia 261 (2005).

Distribution and habitat: $P$. schwartzii is a very widespread species, occurring throughout much of semi-arid W.A. and N.T., extending also to far northern S.A. and into Qld as far east as Aramac. It grows on plains, gravelly rises or stony ridges. Soils may be skeletal or relatively deep, often reddish in colour.

Ptilotus seminudus (J.M.Black) J.M.Black, Fl. S. Austral. 2nd edition, 328 (1948).

Trichinium seminudum J.M.Black, Trans. \& Proc. Roy. Soc. South Australia 40: 61 (1916).

Type: South Australia. Minnipa, 11 November 1915, J.M. Black s.n.; holo AD, n.v.

Cunningham et al. (1981: 289); Benl, Fl. South Austral. 1: 331 (1986); Jacobs \& Lapinpuro, Fl. N.S.W. 1: 259 (1990); Walsh, Fl. Victoria 3: 210 (1996); Elliot \& Jones, Encycl. Australian Pl., Volume 8: 122 (2002).

Illustrations: Benl (1986: 332); Jacobs \& Lapinpuro (1990: 259); Walsh (1996: 211, t. $37 \mathrm{k}-1)$

Distribution and habitat: in eastern Australia, P. seminudus is confined to the northwest of Vic., and the adjacent parts of N.S.W. It is common and widespread in southern parts of S.A., and there is reportedly a disjunct occurrence in W.A. near Esperance.

Ptilotus sessilifolius (Lindl.) Benl, Mitt. Bot. Staatssamml. München 29: 500 (1990).

Trichinium sessilifolium Lindl. in T.Mitch., Three Exped. Australia 2: 12 (1838).

Type: New South Wales. “interior of New Holland” [Byrne’s Creek, N.S.W.], 24 March 1836, T.L. Mitchell 23; holo CGE, digital image at BRI.

Walsh, Fl. Victoria 3: 207-8 (1996); Elliot \& Jones, Encycl. Australian Pl., Volume 8: 123 (2002).

Trichinium atriplicifolium Moq. in A.DC., Prodr. 13(2): 286 (1849); T. obovatum var. atriplicifolium (Moq.) Domin, Biblioth. Bot. 89: 80 (1921); Ptilotus atriplicifolius (Moq.) Benl, Mitt. Bot. Staatssamml. München 2: 404 (1958); Ptilotus atriplicifolius (Moq.) Benl var. atriplicifolius, Mitt. Bot. Staatssamml. München 2: 404 (1958).

Type: New South Wales. Interior of eastern New Holland, swampy-plains, 1817, A. Cunningham s.n.; lecto G-DC, fide Benl (1958).

Benl, Fl. Cent. Austral. 79 (1981); Cunningham et al. (1981: 285); Benl, Fl. South Austral. 1: 324 (1986); Jacobs \& Lapinpuro, Fl. N.S.W. 1: 259 (1990).

Trichinium obovatum var. grandiflorum Benth., Fl. Austral. 5: 221 (1870); Trichinium incanum var. grandiflorum (Benth.) J.M.Black, Trans. \& Proc. Roy. Soc. South Australia 41: 380 (1917); Ptilotus obovatus var. grandiflorus (Benth.) Ewart \& O.B.Davies, Fl. N. Territory 100 (1917).

Type: New South Wales. Harrington Plains, 1817, A. Cunningham s.n.; lecto BM, fide Benl (1990), n.v.

Trichinium elderi Farmar, Bull. Herb. Boissier, sér. 2, 5: 1089 (1905); Ptilotus atriplicifolius var. elderi (Farmar) Benl, Mitt. Bot. Staatssamml. München 2: 404 (1958); Ptilotus 
sessilifolius var. elderi (Farmar) Benl, Mitt. Bot. Staatssamml. München 29: 501 (1990), syn. nov.

Type: Western Australia. Cavenagh Range, 31 July 1891, R. Helms s.n.; holo K, n.v.; iso MEL.

Trichinium incanum var. intermedium Ewart in Ewart \& Jean White, Proc. Roy. Soc. Victoria 22: 97 (1909).

Type: South Australia. Warrina, May 1891, R. Helms s.n.; holo MEL; iso AD (2 sheets).

Ptilotus oblongifolius Gand., Bull. Soc. Bot. France 66: 222 (1919).

Type: New South Wales. Bourke, undated, J.H. Maiden; holo LY, n.v., fide McGillivray, Contr. New South Wales Natl Herb. 4: 353 (1973).

Illustrations: Cunningham et al. (1981: 285), as P. atriplicifolius var. atriplicifolius; Jacobs \& Lapinpuro (1990: 259), as P. atriplicifolius var. atriplicifolius; Milson, Pl. Ident. in Arid Zone 30 (1995); Walsh (1996: 211, t. 37a-b); Moore, Guide Pl. Inland Australia 261 (2005).

Distribution and habitat: $P$. sessilifolius occurs in all mainland states and the N.T., in areas receiving less than about $500 \mathrm{~mm}$ rainfall per annum. It grows on a variety of habitats, including sand dunes, and gravelly rises with clay-loam soil.

Notes: Benl (1981) distinguished var. elderi by its globose spikes "to $4 \mathrm{~cm}$ diameter" vs. globose or cylindric, "to $3 \mathrm{~cm}$ diameter" for the typical variety; spikes mostly solitary (vs. in \pm loose panicles); and leaves "normally 1-1.5 cm wide" (vs. "to $4 \mathrm{~cm}$ wide"). These differences are all very vague, and Benl (loc. cit.) admitted that "transitional forms [are] not infrequent". In 1977, Benl determined the MEL isotype of T. elderi as $P$. atriplicifolius var. atriplicifolius, further evidence of the meaninglessness of the variety. I contend that the recognition of varieties within P. sessilifolius is unsustainable.

Ptilotus spathulatus (R.Br.) Poir. in Lam., Encycl. Suppl. 4: 620 (1816).

Trichinium spathulatum R.Br., Prodr. 415 (1810).

Type: Tasmania. Derwent River, above the fall, 29 March 1804, R. Brown [Bennett No. 3051]; holo BM, n.v.; iso K, n.v.

Bentham, Fl. Austral. 5: 236-7 (1870); Cunningham et al. (1981: 289); Benl, Fl. South Austral. 1: 331 (1986); Jacobs \& Lapinpuro, Fl. N.S.W. 1: 258 (1990); Walsh, Fl. Victoria 3: 209-10 (1996); Elliot \& Jones, Encycl. Australian Pl., Volume 8: 123 (2002).

Illustrations: Cunningham et al. (1981: 289); Jacobs \& Lapinpuro (1990: 258); Walsh (1996: 211, t. 37i-j); Elliot \& Jones, Encycl. Australian Pl., Volume 8: 123 (2002); Moore, Guide Pl. Inland Australia 261 (2005).

Distribution and habitat: $P$. spathulatus is a very widespread species in southern Australia in areas of moderate rainfall. In N.S.W. it occurs west of the Great Divide, south from about Dubbo, and it is common in western Vic. and eastern Tas. It is also common in the southern half of S.A. and the wheatbelt and goldfield areas of W.A.

Note: P. spathulatus has some small verticillate hairs on the tepals, but they are hard to see (hidden by the longer septate hairs). 
Ptilotus spicatus Benth., Fl. Austral. 5: 243 (1870).

Ptilotus spicatus Benth. var. spicatus, Fl. Austral. 5: 243 (1870); Ptilotus spicatus Benth. subsp. spicatus, Mitt. Bot. Staatssamml. München 6: 493 (1967).

Type: Northern Territory. Victoria River, 1855, F. Mueller s.n.; holo K [196971]; iso MEL.

Bentham, Fl. Austral. 5: 243 (1870); Benl, Fl. Cent. Austral. 83 (1981); Wheeler, Fl. Kimb. 132 (1992); Elliot \& Jones, Encycl. Australian Pl., Volume 8: 123-4 (2002).

Ptilotus spicatus var. leianthus Benth., Fl. Austral. 5: 243 (1870); Ptilotus leianthus (Benth.) Domin, Biblioth. Bot. 89: 83 (1921); Ptilotus spicatus subsp. leianthus (Benth.) Benl, Mitt. Bot. Staatssamml. München 6: 493 (1967), syn. nov.

Types: Gulf of Carpentaria, L. Leichhardt; syn K; Flinders R., Qld, 1869, T. Sutherland 91; syn K, MEL; NSW, n.v.; Attack Creek, 1862, J. McDowall Stuart; syn K, MEL; Flinders R., Qld, Bowman; syn ?K, n.v.; syn MEL.

Ptilotus spicatus subsp. burbidgeanus Benl, Mitt. Bot. Staatssamml. München 6: 496 (1967); Ptilotus spicatus var. burbidgeanus (Benl) Benl, Mitt. Bot. Staatssamml. München 15: 173 (1979), syn. nov.

Type: Western Australia. Kimberley Research Stn, Ord R., 26 March 1949, E.C.B. Langfield 59; holo CANB.

Ptilotus spicatus subsp. longiceps Benl, Mitt. Bot. Staatssamml. München 6: 495 (1967), syn. nov.

Type: Northern Territory. Beswick Station, c. 4 miles [6 km] E of homestead, 11 April 1962, D.J. Nelson 257; holo M, n.v.; iso DNA, n.v., NSW.

Illustrations: Wheeler (1992: 131, t. 34E); Milson, Pl. Ident. in Arid Zone 30 (1995); Milson, Pasture Pl. N.W. Qld 13 (2000).

Distribution and habitat: P. spicatus is distributed across tropical Australia from near Derby in W.A. to Hughenden, Qld, mainly away from the coast. It almost extends to the Gulf of Carpentaria, but is absent from the "Top End" of the N.T. It usually inhabits Astrebla-dominated grassland on clay soils, but can also be found on stony plains or sandy soils overlying clay.

Note: Benl (1967b) diagnosed the varieties and subspecies of P. spicatus on the basis of tepal length, the length of the apiculum on the bracteole, and the hairiness of the ovary. These features do vary, but seemingly at random, uncorrelated to other characters, ecological site or distribution.

\section{Excluded species}

Ptilotus fraseri (A.Cunn. ex Moq.) F.Muell., Syst. Census Austral. Pl. suppl. 1, 29 (1884)

Trichinium fraseri A.Cunn. ex Moq. in A.DC., Prodr. 13(2): 295 (1849).

Type: interior of New South Wales, anno 1827, C. Fraser s.n.; iso G-DC, microfiche.

Notes: the label of the type specimen of T. fraseri says "interior of N. S. Wales, 1827, C. Fraser" in the handwriting of Allan Cunningham. However, it is known that in 1827, Charles Fraser collected specimens only around the Swan River in Western Australia. Furthermore, the type specimen appears to be a depauperate form of either 
P. drummondii or P. schwartzii, neither of which occurs in areas of New South Wales that were visited by Fraser.

The identity of $P$. fraseri remains uncertain, and hence it is excluded from this synopsis of eastern Australian species.

\section{Acknowledgments}

I thank the curator of LD for sending a digital image of the type of Ptilotus exaltatus, and the curators of AD, B, BM, CANB, K, MEL and NSW for the loan of type specimens. I am grateful to the Director of the National Herbarium of Victoria (MEL) for allowing access to the herbarium collections during my visit to Melbourne. I thank Terena Lally (CANB) for her encouragement and helpful discussions, and Gordon Guymer for reviewing the manuscript. Juliet Wege (Australian Botanical Liaison Officer 2005-06) and Jenny Tonkin (ABLO 2006-07) kindly provided images of type specimens from CGE, BM and $\mathrm{K}$.

\section{References}

Benl G (1958) Beitrag zu einer Revision der Gattung Ptilotus R.Br. (Amaranthaceae), Mitteilungen der Botanischen Staatssammlung München 1: 401-409.

Benl G (1959) Beitrag zu einer Revision der Gattung Ptilotus R.Br. (Amaranthaceae). 2.Teil., Mitteilungen der Botanischen Staatssammlung München 3: 34-43.

Benl G (1967a) The genus Ptilotus R.Br. Australian Plants 4: 109-124.

Benl G (1967b) Beitrag zu einer Revision der Gattung Ptilotus R.Br. (Amaranthaceae). Mitteilungen der Botanischen Staatssammlung München 6: 493-504.

Benl G (1971) Ein Bestimmungsschlüssel für die Gattung Ptilotus R.Br. (Amaranthaceae), Mitteilungen der Botanischen Staatssammlung München 9: 135-176.

Benl G (1981) Ptilotus. Pp. 76-82 in Jessop JP (ed.) Flora of Central Australia. (Australian Systematic Botany Society: Reed, Sydney)

Benl G (1983) Taxonomic studies on Ptilotus R.Br. (Amaranthaceae) in Western Australia. Nuytsia 4: 263-274.

Benl G (1984) A new subspecies of Ptilotus distans (R.Br.) Poir. in Queensland. Austrobaileya 2: 17.

Benl G (1986) Ptilotus. Pp. 321-332 in Jessop JP \& Toelken HR (eds) Flora of South Australia, vol. 1. (South Australian Government Printing Division: Adelaide)

Bentham G (1870) Amaranthaceae. Pp. 208-258 in Flora Australiensis, vol. 5. (L. Reeve \& Co.: London)

Chapman AD (1991) Australian Plant Name Index, vols 1-4. Australian Flora and Fauna Series 12. (Australian Government Publishing Service: Canberra).

Cunningham GM, Mulham WE, Milthorpe PL \& Leigh JH (1981) Plants of Western New South Wales. (N.S.W. Government Printing Office: Australia).

Jacobs SWL \& Lapinpuro L (1990) Ptilotus. Pp. 256-260 in Harden GJ (ed.) Flora of New South Wales, vol. 1. (New South Wales University Press: Sydney)

Lee KK, Harrison DK, Johnston ME \& Williams RR (2007) Molecular taxonomic clarification of Ptilotus exaltatus and Ptilotus nobilis (Amaranthaceae). Australian Systematic Botany 20(1): 72-81.

Walsh NG (1996) Amaranthaceae. Pp. 199-215 in Walsh NG \& Entwisle TJ (eds) Flora of Victoria, vol. 3. (Inkata Press: Melbourne)

Wheeler JR (1992) Amaranthaceae. Pp.106-133 in Wheeler JR (ed.) Flora of the Kimberley Region. (Department of Conservation and Land Management: Como) 